\title{
Hawālah sebagai Alternatif Pembiayaan Multijasa di Lembaga Keuangan Syariah
}

\author{
Ahmad Syakur \\ Sekolah Tinggi Agama Islam (STAIN) Kediri \\ ahmadsyakur08@gmail.com
}

\begin{abstract}
:
Islamic banking and other Islamic financing institution need more inovation and to multiply the kind of transaction so that not to stay behind by conventional financing instituon. In the otherhand, hawālah that we know in the study of fiqh mu'amalah do not develop optimately in the Islamic economy institution. The application of hawālah in Islamic banking is little and not popular, whereas by little inovation, hawālah can be the alternative transaction.

This article is an exertion to create the financing concept of multijasa Islamic Banking that more acceptable and more simple by using the hawālah contract with little inovation. That is the combination between hawālah bi al-ujrah contract and wakālah contract, as the alternative financing for increasing monetary instruments bases the sharia. So the strong and healty financing institution is realized without leaving the sharia.
\end{abstract}

Keywords: multijasa Islamic banking, inovation, hawalah bi al-ujrah

\section{Pendahuluan}

Lembaga keuangan konvensional terus berkembang dan inovasi produk terus bermunculan. Di sisi lain Lembaga Keuangan Syariah (LKS), baik bank maupun non-bank pada saat ini masih tercitrakan sebagai lembaga keuangan yang kurang aplikatif dan kurang kompetitif. Belum lagi ia dipenuhi dengan istilah arab yang kurang dapat dipahami oleh masyarakat awam, sehingga memunculkan kesan bahwa LKS hanya mengganti istilah ke dalam bahasa Arab, sedang operasionalnya sama dengan perbankan konvensional. Ini tak lain adalah akibat ketidakpahaman masyarakat terhadap istilah-istilah 
Arab serta implikasi, konsekuensi dan perbedaannya dengan operasional lembaga keuangan konvensional.

Pasar LKS baik dari segi jenis produk maupun asetnya masih jauh di bawah potensi yang sesungguhnya. Oleh karena itu perlu dilakukan pengembangan instrumen LKS secara terus-menerus yang mengarah kepada marketabilitas, negosiabilitas dan transferabilitas iklim keuangan yang menciptakan likuiditas dengan perluasan menu pilihan yang sesuai bagi nasabah (Muhamad, 2004: 47-48). Marketabilitas produk LKS harus menjadi fokus inovasi, sehingga ia dapat melakukan persaingan secara wajar dengan lembaga keuangan konvensional dalam merebut calon nasabah penabung maupun peminjam. Karena itu LKS harus memperhatikan tren pasar. Perubahan tren pasar harus diikuti dan direspon oleh LKS, misalnya tren perubahan modus kredit perbankan dengan semakin besarnya kredit konsumtif dibanding kredit produktif.

Menurut data Statistik Perbankan Indonesia yang dikeluarkan oleh Bank Indonesia menunjukkan bahwa pada Desember 2005, dari jumlah 695,65 istiṣna' outstanding kredit perbankan di Indonesia 29,95\% atau 206,69 triliun di antaranya adalah kredit konsumtif. Angka ini terus meningkat, per desember 2009 meningkat menjadi 30,39\% atau 436,989 istișna' dan per April 2010 meningkat menjadi 32,59\% atau 484,375 istiṣna' (Bank Indonesia, April 2010: 132). Data ini belum mencakup kredit konsumtif yang diberikan secara tidak langsung, yaitu pembiayaan yang diberikan kepada sektor jasa dunia usaha, yang isinya sebagian besar merupakan kredit kepada multifinance, koperasi simpan pinjam dan institusi lainnya yang meneruskan pembiayaan konsumtif kepada nasabahnya. Dengan demikan, sebenarnya lebih dari $40 \%$ outstanding kredit yang diberikan perbankan Indonesia disalurkan kepada kredit konsumtif.

Berdasarkan data di atas, dapat kita lihat bahwa pembiayaan konsumtif semakin meningkat kontribusinya. Hal ini juga menunjukkan bahwa masyarakat yang mengajukan pembiayaan atau kredit dari lembaga keuangan yang terbanyak adalah kaum pekerja dan karyawan, termasuk PNS, yang secara ekonomi termasuk kalangan menengah. Hal ini terjadi karena mengikuti tren budaya hidup masyarakat dan kemajuan teknologi. Oleh sebab itu bila LKS ingin terus berkembang, ia harus memperbanyak jenis pembiayaan di sektor ini. 
Pada awalnya LKS terkesan tidak memprioritaskan pembiayaan konsumtif ini. Terbukti bahwa bank syariah pada awalnya diidentikkan dengan bank bagi hasil, merujuk kepada salah satu skim pembiayaannya yang bersifat produktif dengan akad mushārakah dan muḍārabah. Bahkan banyak ekonom muslim yang terkesan membatasi LKS agar tidak banyak memberikan porsi pembiayaan konsumtif dan disarankan agar berhati-hati. Hal ini karena maksimalisasi pembiayaan konsumtif akan mendorong budaya hidup konsumtifisme yang bertentangan dengan ajaran Islam (Chapra, 2000: 86-87). Penulis tidak sependapat dengan asumsi di atas, karena bagaimanapun pembiayaan konsumtif tidak selamanya negatif. Banyak masyarakat membutuhkan pembiayaan konsumtif untuk meringankan hidupnya, yang seringkali hal itu berkaitan erat dengan produktifitas kerja. Misalnya seorang pedagang kecil ingin membeli sepeda motor, walaupun ini merupakan kebutuhan konsumtif, tetapi jika dengan sepeda motor tersebut biaya ongkos transpor belanja menjadi lebih murah dan lebih cepat, atau urusan mengantar anaknya ke sekolah lebih cepat dan mudah, hal ini tentu akan meningkatkan produktifitas kerjanya.

Konsumsi dan produksi adalah dua hal yang beririsan secara ekonomi. Keduanya saling berhubungan secara mutualisme dan saling mempengaruhi. Pembiayaan konsumtif secara tidak langsung akan meningkatkan kapasitas produksi dan menghidupkan pasar. Kenaikan daya beli masyarakat walaupun ditopang oleh pembiayaan konsumtif akan menggairahkan pasar dan produksi, yang secara makro akan menyebabkan ekonomi menjadi baik. Sebaliknya penyimpangan dalam konsumsi dengan membudayanya hidup komsumtif juga tidak lepas dari pengaruh produksi. Perluasan pembiayaan produktif yang tidak terkontrol juga akan melahirkan budaya negatif. Karena itu menurut penulis, perbankan syariah harus mendorong dua komponen pembiayaan tersebut, produktif dan konsumtif dengan tetap memberikan pengawasan dan rambu-rambu agar masyarakat tidak terbawa arus komsumtifisme yang berlebihan.

Selama ini, LKS mengandalkan produk murābahah untuk pembiayaan konsumtif ini, walaupun tidak semua pembiayaan murābahah adalah pembiayaan konsumtif. Data statistik perbankan Indonesia menunjukkan bahwa kontribusi murābaḥah sangat dominan dalam pembiayaan syariah, yaitu 62,3 
\% pada Desember 2005 dan 55,99\% pada April 2010 (Bank Indonesia, April 2010: 146). Penurunan persentase murābaḥah pada April 2010 bila dibandingkan Desember 2005 tidak berarti menurunnya pembiayaan konsumtif, tapi lebih disebabkan semakin beragamnya produk pembiayaan konsumtif syariah.

Di sisi lain, walaupun LKS telah meluncurkan produk pembiayaan konsumtif lain, di antaranya berupa produk pembiayaan ijārah (IMBT) dan multijasa Islamic Bank (IB), namun kontribusinya di pasar masih sangat kecil. Data terakhir BI memasukkan pembiayaan ini pada indikator lainnya (others) yang mencakup semua layanan pembiayaan perbankan di luar pembiayaan mushārakah, muḍārabah, murābaḥah dan istiṣnā', yang kontribusinya per April 2010 hanya 7,3\% dari total pembiayaan perbankan syariah (Bank Indonesia, 2010: 146).

Dominasi produk murābaḥah dalam skim pembiayaan konsumtif berakibat tidak baik, karena sebenarnya kebutuhan pembiayaan konsumtif nasabah adalah sangat beragam. Dari keragaman itu banyak di antaranya yang tidak dapat diaplikasikan dalam bentuk pembiayaan murābaḥah. Idealnya pengembangan produk multijasa perbankan syariah ini tidak mengurangi jumlah pembiayaan murābaḥah, tetapi memperluas jangkauan pembiayaan syariah dalam hal yang selama ini belum dapat dijangkau. Walaupun begitu munculnya produk multijasa ini dapat mengurangi dominasi murābaḥah, karena dua alasan berikut: 1) Pada masa lalu, banyak nasabah atau LKS yang melakukan transaksi pembiayaan murābaḥah secara terpaksa namun tetap halal untuk pembiayaan konsumtif yang diperlukan, karena tidak ada alternatif lain yang lebih sederhana, sehingga ketika ada alternatif yang lebih sederhana dan aplikatif, maka ia menjadi pilihan; 2) Dominasi pembiayaan murābahah dalam pembiayaan konsumtif perbankan syariah dapat melahirkan penyimpangan operasional di lapangan. Banyak kebutuhan konsumtif nasabah yang secara fikih tidak dapat dimasukkan dalam pembiayaan murābahah, seperti biaya rumah sakit, pendidikan dan lainnya, tetapi oleh LKS dimasukkan secara paksa ke dalam skim murābahah. Penyimpangan praktek murābaḥah di lapangan inilah yang menjadi salah satu sebab munculnya opini masyarakat bahwa bank dan LKS sama saja dengan bank dan lembaga keuangan konvensional. Karena itu penyimpangan ini seharusnya 
juga bisa diminimalisir (ditiadakan) dengan adanya produk alternatif bagi kebutuhan konsumtif, yaitu pembiayaan multijasa perbankan syariah.

Pertanyaannya adalah, mengapa produk pembiayaan multijasa belum banyak menjadi alternatif pilihan? Apakah semata-mata karena ia merupakan produk baru yang belum banyak dikenal masyarakat, ataukah produk ini belum aplikatif, prosesnya masih rumit, kurang kompetitif dan marketable? Jika penyebabnya adalah produk baru, maka perlu memperbanyak sosialisasi produk pada masyarakat. Namun jika penyebabnya yang kedua, maka tugas ahli ekonomi Islam untuk merumuskan inovasi yang lebih aplikatif, kompetitif dan marketable.

Terlepas dari di mana letak permasalahannya, dalam paper ini akan ditulis tentang kontribusi keilmuan berupa rumusan konsep inovasi pembiayaan multijasa yang dianggap lebih efisien dan lebih aplikatif jika dibandingkan dengan produk pembiayaan multijasa yang selama ini dipraktekkan di lembaga keuangan syariah.

\section{Pembahasan}

Pembiayaan multijasa yang selama ini dipraktekkan oleh LKS di Indonesia adalah pembiayaan multijasa dengan dasar akad ijārah atau kafālah sebagaimana fatwa Dewan Syariah Nasional (DSN) MUI no. 44/DSN-MUI/ VII/2004 tentang pembiayaan multijasa. Fatwa DSN tersebut secara umum membolehkan pembiayaan multijasa dengan ketentuan sebagai berikut: 1) Pembiayaan Multijasa hukumnya boleh (jāiz) dengan menggunakan akad ijārah atau kafālah; 2) Dalam hal LKS menggunakan akad ijārah, maka harus mengikuti semua ketentuan yang ada dalam Fatwa Ijārah; 3) Dalam hal LKS menggunakan akad kafālah, maka harus mengikuti semua ketentuan yang ada dalam Fatwa Kafālah; 4) Dalam kedua pembiayaan multijasa tersebut, LKS dapat memperoleh imbalan jasa (ujrah) atau fee; 5) Besar ujrah atau fee harus disepakati di awal dan dinyatakan dalam bentuk nominal bukan dalam bentuk persentase.

Namun Pembiayaan multijasa baik dengan akad ijārah maupun dengan akad kafālah, tidak dapat diterapkan begitu saja untuk berbagai kebutuhan nasabah. Hal ini karena jika produk multijasa tersebut berdasar akad ijārah, 
maka ia terikat dengan ketentuan ijärah, dalam rukun, syarat, maupun ketentuan lainnya, sebagaimana ditetapkan dalam fatwa DSN MUI tentang pembiayaan multijasa di atas. Dalam fatwa DSN MUI nomor 09/DSN-MUI/ /IV/2000 tentang Pembiayaan Ijārah disebutkan bahwa objek akad ijārah adalah manfaat barang dan sewa atau manfaat jasa dan upah. Begitu juga fatwa tersebut menjelaskan bahwa di antara ketentuannya adalah objek ijärah adalah manfaat dari penggunaan barang dan atau jasa dan manfaat barang atau jasa tersebut harus dapat dinilai dan dapat dilaksanakan dalam kontrak.

Para ahli fikih berbeda-beda redaksinya dalam mendefinisikan ijärah, namun secara umum subtansinya sama. Di antara definisi ijārah yang sederhana adalah yang dinukil oleh 'Aishah al-Sharqawi, yaitu jual beli manfaat tertentu dengan harga/pengganti tertentu ('Aishah al-Sharqawi, 2000: 506). Ijärah dalam pemahaman ulama-ulama fikih diklasifikasikan ke dalam dua kelompok, yaitu kelompok sewa-menyewa dan kelompok upahmengupah. Kedua pengertian ini dalam terminologi fikih sama-sama menggunakan istilah ijärah.

Akad Ijārah dalam pengertian sewa-menyewa didefinisikan sebagai akad pemindahan hak guna atas barang melalui pembayaran upah sewa tanpa diikuti dengan pemindahan kepemilikan atas barang tersebut (Syafi'i Antonio, 2001: 117). Akad ijārah digunakan untuk objek transaksi berupa barang yang tidak habis dipakai atau barang yang apabila telah habis masa sewanya dapat dikembalikan kepada pemiliknya seperti rumah, gedung, kantor, ruko, kendaraan, hewan dan lainnya. Dalam konteks ini, LKS berfungsi sebagai pihak yang menyewakan (mu'ajjir) dan nasabah sebagai pihak yang menyewa (musta'jir).

Berdasar ketentuan di atas, pembiayaan multijasa jika menggunakan akad ijārah dalam pengertian sewa-menyewa rumit untuk dilakukan. Hal ini karena LKS tidak mempunyai aset/barang yang dapat disewakan ke nasabah sehingga LKS tidak dapat secara langsung menyewakan barangnya ke nasabah, tetapi LKS harus memiliki barang tersebut terlebih dahulu dengan akad sewa atau jual beli. Apalagi biasanya nasabah ingin mencari sendiri barang yang akan disewa. Karenanya alternatif pembiayaan ini adalah dengan menggunakan ijārah paralel. Ijārah paralel berarti melaksanakan dua transaksi ijārah (sewa) antara bank dan pihak ketiga, juga antara bank dengan 
nasabah secara simultan. Mirip dengan salam paralel yang telah dikenal dalam perbankan syariah. Kemudian untuk mengakomodasi keinginan nasabah mencari barang sesuai keinginannya dan untuk mempermudah kerja LKS maka diperlukan akad wakālah (perwakilan) dari bank ke nasabah untuk melakukan sewa atas barang kepada pihak ketiga atas nama LKS. Akad ijārah antara nasabah dengan LKS baru dapat dilakukan setelah barang tersebut secara hukum telah disewa oleh LKS. LKS mendapat keuntungan dari selisih harga sewa pertama (harga sewa pihak ketiga ke LKS) dengan harga sewa kedua (harga sewa LKS ke nasabah).

Sedangkan akad Ijārah dalam pengertian upah-mengupah digunakan untuk objek pekerjaan/jasa yaitu akad untuk melakukan pekerjaan tertentu dengan pembayaran upah, seperti upah pekerja pabrik, buruh tani, tukang kebun, karyawan perusahaan dan lainnya. Dalam konteks LKS, ijārah dalam pengertian upah-mengupah diilustrasikan bahwa LKS melakukan pekerjaan tertentu atas permintaan nasabah dengan pembayaran upah yang disebut ujrah/fee. Di sini LKS berfungsi sebagai musta'jir (orang yang menerima upah), sedang nasabah sebagai mu'ajjir (orang yang memberi upah). Misalnya dalam pembiayaan pendidikan, nasabah meminta LKS untuk melakukan jasa pengurusan anaknya untuk memasuki bangku sekolah/kuliah. Dalam hal ini LKS harus melakukan pekerjaan pengurusan tersebut sehingga ia berhak atas imbalan/fee dari kerja pengurusannya itu. Besaran upah (ujrah/ fee) harus disepakati di awal dan dinyatakan dalam bentuk nominal bukan dalam bentuk persentase (Lihat Fatwa DSN-MUI No. 44/DSN-MUI/VII/2004 tentang pembiayaan multijasa ketentuan umum no 5).

Kelemahan akad ini terletak pada kerja yang harus dilakukan oleh LKS yang kebanyakan kekurangan SDM tenaga untuk melakukan pembayaran, kecuali bagi LKS yang sudah melakukan kerjasama atau pihak ketiga membuka akses online. Kelemahan ini tidak dapat diatasi misalnya dengan melakukan akad wakālah (perwakilan) kepada nasabah kembali. Kasus seperti ini tidak diperbolehkan secara fikih, karena logika dari akad ini adalah nasabah datang ke LKS meminta lembaga keuangan mengurusi urusannya dengan imbalan upah. Tapi kemudian oleh lembaga keuangan pengurusan tersebut diwakilkan kepada nasabah kembali tanpa imbalan atas wakālah tersebut. Justru LKS yang menerima imbalan dari pekerjaan yang 
sebetulnya secara riil tidak dilakukannya. Kasus ini mirip dengan jual beli 'inah yang dilarang oleh mayoritas ulama fikih karena menjadi hịlah untuk mendapatkan imbalan tanpa padanan yang dibenarkan secara shar'i (riba). Jual beli 'inah menurut fukaha yaitu seseorang menjual barang dengan tempo kemudian membelinya kembali barang tersebut secara tunai dengan harga lebih murah. Para ahli fikih melarang jual beli ini karena sebagai siasat untuk mengambil riba dengan cara lain, juga berdasarkan hadits Abu Dawud yang berbunyi, "Jika kamu berjual beli secara 'inah, maka Allah membelenggukan atas kamu kehinaan yang tidak dapat dilepaskan sampai kamu kembali kepada agamamu" (Lihat: al-Salus, 2004: 264-265). Bedanya kalau dalam jual beli 'inah, objek akadnya adalah jual beli padahal kedua belah pihak tidak menginginkan akad jual beli tersebut, akad jual beli hanya hịlah untuk mendapatkan imbalan. Sedang dalam kasus ini yang menjadi objek adalah akad ijārah padahal kedua belah pihak sebenarnya tidak menghendaki akad ijārah tersebut. Akad ijārah hanya menjadi hịlah pihak bank untuk mendapat imbalan (riba).

Karena itu pembiayaan multijasa berdasar akad ijärah yang berarti upah-mengupah atas jasa yang dilakukan, mengharuskan pihak LKS secara riil melakukan pekerjaan jasa tersebut, atau melimpahkan kepada pihak lain selain nasabah, baik atas dasar akad wakālah maupun ijārah. Apabila yang digunakan adalah akad wakālah, LKS dapat mengambil keuntungan dari margin antara fee yang dia berikan kepada pihak ketiga yang mengurusi keperluan nasabah tersebut dengan fee yang dia terima dari nasabah. Sedangkan apabila yang dipergunakan adalah akad ijārah, akan berefek pada tingginya fee yang ditanggung nasabah, karena sebenarnya fee tersebut dibagi berdua, yakni bank dan pihak ketiga yang melakukannya. Tingginya fee yang ditanggung nasabah menjadikan pembiayaan ini tidak kompetitif. Belum lagi tidak semua nasabah cocok dengan pihak ketiga tersebut. Yang jelas, kedua alternatif di atas, hanya terbatas pada lembaga yang telah menjalin kerjasama dengan pihak LKS.

Sedang jika produk pembiayaan multijasa tersebut menggunakan akad kafālah, maka itu terikat dengan hukum kafālah, dari sisi rukun, syarat dan ketentuan lainnya sebagaimana disebutkan dalam fatwa DSN MUI tentang Pembiayaan Multijasa di atas. 
Kafālah secara bahasa berarti menjamin, sedang secara terminologi fikih, para ahli berbeda dalam memberikan definisi berdasarkan perbedaan mereka tentang kafālah. Ahli fikih Mālikiyyah, Shāfi'iyyah dan Ḥanābilah mendefinisikan kafālah sebagai penggabungan tanggungan penjamin ke tanggungan orang yang dijamin dalam menetapi hak (Zuhayli, 2007: 4143). Sedang ahli fikih Ḥanāfiyyah mendefinisikan kafālah sebagai penggabungan tanggungan seseorang ke tanggungan orang lain dalam tuntutan (Zuhayli, 2007: 4144).

Dari definisi fikih di atas disimpulkan bahwa secara umum kafālah adalah akad pemberian jaminan yang diberikan satu pihak kepada pihak lain di mana pemberi jaminan bertanggung jawab atas pembayaran kembali suatu utang yang menjadi hak penerima jaminan.

Berdasar definisi kafālah di atas, jika pembiayaan multijasa menggunakan akad kafālah, maka LKS dalam hal ini berfungsi sebagai kāfil (penjamin) saja. Artinya ketika nasabah meminta pembiayaan multijasa, nasabah diharuskan belum mempunyai tanggungan ke pihak lain. Hal ini karena fungsi kafālah adalah sebagai penguat saja. Kafālah itu biasanya atas inisiatif atau permintaan calon pemberi piutang agar ia aman bertransaksi karena ada jaminan. Jika kafālah tersebut atas inisiatif/permohonan orang yang berutang maka ia dapat berfungsi dua: 1) Sebagai penguat di hadapan calon pemberi piutang agar dia percaya dan aman bertransaksi karena adanya kāfil yang menjamin terbayarnya utang; 2) Atau kafālah tersebut sebagai penguat atas diri pengutang sendiri untuk berani melakukan transaksi yang menimbulkan utang karena ada jaminan dari kāfil. Jika terjadi sesuatu, akan ada dana talangan dari kāfil.

Dengan demikian pembiayaan multijasa dengan akad kafālah kurang akomodatif dan kurang efisien baik waktu maupun tenaga. Hal ini karena dalam pembiayaan ini berlaku ketentuan:

a) Akad kafālah hanyalah akad penjaminan, sehingga ketika LKS melakukan pembiayaan multijasa berdasar akad kafālah, seharusnya pada saat itu ia tidak secara langsung memberikan dana talangan yang berwujud qarḍ (pinjaman tanpa bunga) kepada nasabah. Jika LKS langsung memberikan qarḍ pada saat itu maka tidak berlaku akad kafālah, tetapi akad qarḍ saja; 
b) Karena itu dana talangan tersebut hanya dapat diberikan ketika nasabah tidak dapat membayar tanggungannya, saat jatuh tempo, bukan pada saat akad kafālah. Inilah yang dimaksudkan oleh Direktorat Perbankan Syariah Bank Indonesia dalam buku Kodifikasi Produk Perbankan Syariah tentang Pembiayaan Multijasa dengan akad kafālah pada poin terakhir yang berbunyi, "Dalam hal nasabah tidak dapat memenuhi kewajiban kepada pihak ketiga, maka bank melakukan pemenuhan kewajiban nasabah kepada pihak ketiga dengan memberikan dana talangan sebagai pembiayaan atas dasar akad al-qard yang harus diselesaikan oleh nasabah". Jadi dana talangan itu konsekuensi dari akad kafālah, yang mana kāfil (penjamin/LKS) bertanggungjawab atas kelancaran pembayaran utang nasabah kepada pihak ketiga.

c) Walaupun dana talangan merupakan konsekuensi dari kesediaan LKS menjadi kāfil bagi nasabah, namun tidak semua akad kafālah berujung pada pemberian dana talangan. Talangan hanya bersifat kasuistik, yaitu ketika terjadi kasus nasabah tidak dapat melakukan pembayaran kepada pihak ketiga sesuai perjanjian. Ini artinya ketika melakukan pembiayaan multijasa berdasar akad kafālah, ia tidak harus mengeluarkan dana talangan. Padahal realitasnya ketika calon nasabah meminta pembiayaan multijasa, ia butuh uang dan ia berharap pulang dari bank dengan membawa uang untuk membiayai kebutuhannya.

d) Fee dalam kafālah tidak bergantung pada pemberian dana talangan. LKS memberikan dana talangan maupun tidak, nasabah tetap berkewajiban membayar fee ke bank sebagai imbalan atas jasa kafālah.

Dengan pertimbangan beberapa poin di atas dapat disimpulkan bahwa pembiayaan multijasa berdasar akad kafālah agak sulit dan rumit untuk diterapkan. Mungkin pertimbangan ini pulalah yang menyebabkan kebanyakan LKS tidak memakai akad ini dalam pembiayaan multijasa, melainkan memakai akad ijārah.

\section{Hawālah sebagai Alternatif Pembiayaan Multijasa pada LKS}

Berdasar keterbatasan pembiayaan multijasa sebagaimana dikemukakan di atas, penulis mengusulkan akad alternatif bagi pembiayaan mul- 
tijasa selain yang telah difatwakan oleh DSN MUI di atas. Alternatif itu adalah pembiayaan multijasa berdasar akad ḥawālah. Pembiayaan multijasa dengan menggunakan akad hawālah ini penulis yakini dapat lebih fleksibel, lebih mudah dan lebih sederhana jika dibandingkan dengan menggunakan akad ijārah maupun kafālah, sehingga dapat lebih kompetitif. Diharapkan dengan adanya alternatif ini pembiayaan multijasa secara umum akan lebih fleksibel karena ada beberapa pilihan akad yang sesuai dengan kebutuhan nasabah.

Ḥawālah atau ḥiwālah secara bahasa berarti al-tahwīl dan al-intiqāl yang berarti memindahkan dari satu tempat ke tempat lain Wahbah (Zuhayli, 2007: 4187; Hammād, 1995: 147). Sedang secara terminologi fikih, para ahli berbeda dalam mendefinisikannya. Mayoritas ahli fikih mendefinisikannya sebagai "pemindahan tanggungan (utang) dari tanggungan seseorang kepada tanggungan orang lain" (Zuhayli, 2007:4187-4188; Ḥammād, 1995: 147).

Sedang menurut Ḥanafiyah, ḥawālah adalah "Pemindahan tuntutan (tagihan) dari tanggungan orang yang punya utang kepada tanggungan orang lain yang beriltizam menanggungnya" (Zuhayli, 2007: 4187-4188; Hammād, 1995: 147).

Hawālah merupakan pengalihan utang dari orang yang berutang kepada orang lain yang wajib menanggungnya. Dalam hal ini terjadi perpindahan tanggungan atau hak dari satu orang kepada orang lain. Dalam istilah ulama, hawālah adalah pemindahan beban utang dari muhịil (orang yang berutang) menjadi tanggungan muḥāl 'alaih (orang yang berkewajiban membayar utang).

Hawālah dalam utang ini dibolehkan secara shar'i sebagai bentuk pengecualian dari larangan bertasaruf dalam utang dengan utang. Kebolehan ḥawālah ini berdasar al-Sunnah dan ijma (konsensus) ahli fikih. Al-Sunnah yang menunjukkan kebolehan ḥawālah, adalah sabda Rasulullah saw:

"Menunda-nunda pembayaran (utang) bagi orang yang mampu adalah suatu kezaliman. Dan jika salah seorang dari kamu di-ḥawālah-kan (dipindahkan utangnya) kepada orang yang mampu/kaya, maka terimalah ḥawālah itu” (HR. Ahmad, al-Ṭabrani dan lain-lain). 
Walaupun dalam sanad hadis ini ada kelemahan (ḍa'íf) namun ia menjadi kuat dan dapat dijadikan sandaran hukum karena diriwayatkan dari jalur-jalur lain yang saling menguatkan (al-Ṣan'āni, 1991: 115-117)

Sedangkan ijma, para ulama bersepakat untuk membolehkan ḥawālah secara global. Ia merupakan akad yang dibolehkan dalam utang dan tidak dibolehkan dalam bentuk barang, karena ia merupakan pemindahan secara hukum, dan itu tidak terjadi pada barang (Zuhayli, 2007: 4189).

Utang atau tanggungan sebagai objek ḥawālah adalah harta yang wajib ditunaikan dalam tanggungan seseorang baik akibat dari akad, kerusakan atau pinjaman ('Atiqi, 1998: 286-287). Utang atau tanggungan akibat akad misalnya jual beli secara kredit dan jual beli salam. Tanggungan akibat kerusakan misalnya seseorang meminjam motor kemudian motornya rusak akibat kecelakaan.

\section{Jenis-Jenis Hawālah}

Akad ḥawālah berdasarkan jenis objek ḥawālah dibagi menjadi dua jenis ḥawālah, yaitu ḥawālah dayn dan ḥawālah ḥaq. Hawālah dayn adalah pemindahan kewajiban melunasi utang kepada orang lain. Sedangkan ḥawālah ḥaq adalah pemindahan kewajiban hak (piutang) kepada orang lain. Perbedaan ḥawālah dayn dan ḥawālah ḥaq terletak pada siapa yang berinisiatif melakukannya. Jika yang berinisiatif melakukan adalah orang yang berutang maka ia adalah ḥawālah dayn. Sedang jika yang melakukannya orang yang berpiutang maka ia adalah ḥawālah ḥaq (Zuhayli, 2007: 4197). Berdasarkan definisi ini, maka anjak piutang (factoring) yang terdapat pada praktik perbankan, termasuk ke dalam kelompok ḥawālah ḥaq, bukan ḥawālah dayn.

Di samping pembagian di atas, ahli fikih Hanafiyyah membagi ḥawālah menjadi ḥawālah muqayyadah dan ḥawālah muṭlaqah. Hawālah muqayyadah menurut mereka adalah pemindahan utang dari seseorang kepada tanggungan orang lain yang mempunyai utang kepadanya dengan menyebutkan bahwa ḥawālah tersebut terjadi pada tanggungan (utang) yang wajib dibayar oleh orang lain tersebut kepada pihak yang melakukan hawālah. Sedang ḥawālah muṭlaqah menurut mereka, sebagaimana dinukil oleh Zuhayli, adalah seseorang memindahkan tanggungan utangnya kepada orang 
lain dan tidak membatasinya dengan utang yang ditanggung oleh orang lain tersebut (Zuhayli, 2007: 4194-4195). Secara lebih terinci dijelaskan oleh Nazih Ḥammād bahwa ḥawālah muṭlaqah adalah ḥawālah yang tidak dibatasi pembayaran utang yang dialihkan berasal dari harta orang yang melakukan pengalihan utangnya tersebut (muhịi) yang berada dalam tanggungan orang yang dipindahi pembayaran utangnya (muḥāl 'alaih). Pembayaran utang tersebut (kepada pihak ketiga) diambilkan dari harta pihak muḥāl 'alaih tersebut, baik orang tersebut (muhịi) mempunyai piutang kepadanya (muḥāl 'alaih) atau tidak (Ḥammād, 1995: 147-148).

Ulama Ḥanāfiyyah membolehkan kedua jenis ḥawālah tersebut, namun ḥawālah muṭlaqah menurut Ḥanafiyyah hanya boleh pada ḥawālah dayn. Sedang mayoritas ahli fikih hanya membolehkan ḥawālah muqayyadah. Pendapat ulama Hanāfiyyah inilah yang dipegang oleh DSN MUI dalam fatwanya No. 58/DSN-MUI/V/2007 tentang ḥawālah bi al-ujrah. Dalam fatwa tersebut, DSN menyatakan bahwa Hawālah muqayyadah adalah ḥawālah di mana muhỉl adalah orang yang berutang sekaligus berpiutang kepada muḥāl 'alaih sebagaimana dimaksud dalam Fatwa No.12/DSN-MUI/ IV/2000 tentang Ḥawālah. Sedang ḥawālah muṭlaqah adalah ḥawālah di mana muhīl adalah orang yang berutang tetapi tidak berpiutang kepada muḥāl 'alaih. Selanjutnya dalam fatwa tersebut dikatakan bahwa hawālah bi alujrah hanya berlaku pada ḥawālah muṭlaqah, sehingga dalam ḥawālah muṭlaqah, muḥāl 'alaih boleh menerima ujrah/fee atas kesediaan dan komitmennya untuk membayar utang muhịil yang besarnya fee tersebut harus ditetapkan pada saat akad secara jelas, tetap dan pasti sesuai kesepakatan para pihak.

\section{Syarat Utang yang Menjadi Objek Hawālah (Muḥāl Bih)}

Utang yang menjadi objek ḥawālah, menurut jumhur disyaratkan utang tersebut bersifat lāzim dalam arti utang tersebut adalah utang yang wajib ditunaikan seperti utang yang ditimbulkan dari utang-piutang atau jual beli kredit. Menurut jumhur fukaha, hawāalah tidak boleh dilakukan pada utang yang ghayr lāzim (tidak harus ditunaikan) seperti utang yang berupa harga jual beli pada masa khiyār. Utang ini bersifat ghayr lāzim dalam arti dapat dibatalkan. Sedangkan ulama madzhab Hambali membolehkan 
ḥawālah pada utang yang ghayr lāzim. Begitu juga ulama madzhab Shāfi'i membolehkan ḥawālah pada utang yang akan menjadi lāzim secara sendirinya, seperti utang yang berupa harga jual beli yang disertai khiyār pada saat akad, utang mahar sebelum dikumpuli, upah pekerja sebelum selesai pekerjaannya, serta upah sewa sebelum selesai waktu pemanfaatannya (Zuhayli, 2007: 4193).

Dari keterangan di atas, pendapat ulama madzhab Hambali dan Shafi'i yang membolehkan utang ghayr lāzim sebagai objek ḥawālah, adalah lebih aplikatif, dengan syarat jika utang yang ghayr lāzim tersebut tidak jadi ditunaikan atau gugur kewajiban pembayarannya, pihak pengutang (muhịil) harus membatalkan ḥawālahnya. Hal ini karena tidak adanya nas yang mengharuskan itu, juga demi kemudahan dan kemaslahatan. Dengan demikian, di antara ekses pendapat tersebut adalah ḥawālah diperbolehkan pada utangutang seperti biaya pendidikan bagi orang yang sudah mendaftarkan diri atau anaknya di sekolah tersebut, walaupun utang ini bersifat ghayr lāzim, karena dapat dibatalkan atau tidak dibayar. Karena itu perbankan syariah boleh melakukan akad ḥawālah pada utang-utang yang ghayr lāzim seperti di atas.

\section{Aplikasi Hawālah dalam Transaksi LKS}

Selama ini implementasi akad hawālah bi al-ujrah tersebut dalam LKS sangat minim. Bahkan kalau kita lihat daftar produk perbankan syariah yang dikeluarkan oleh direktorat Perbankan Syariah Bank Indonesia, tidak ada satupun produk perbankan syariah di Indonesia yang menggunakan akad ḥawālah (lihat www.bi.go.id). Namun secara umum, akad ḥawālah dapat diaplikasikan dalam produk jasa transfer (kiriman uang) dan debt transfer atau anjak piutang (factoring) yang mana fasilitas ḥawālah lazimnya untuk membantu supplier mendapatkan modal tunai agar dapat melanjutkan produksinya. Bank atau Lembaga Keuangan Syariah lainnya mendapat upah/ fee atas jasa pemindahan piutang (Antonio, 2001: 126-127; Muhamad, 2004: 87). Ini bagi yang berpendapat bahwa anjak piutang syariah dapat menggunakan akad hawālah. Sedangkan DSN MUI dalam fatwanya menetapkan bahwa anjak piutang syariah tidak memakai akad ḥawālah, melainkan menggunakan akad wakālah bi al-ujrah. 
Sebetulnya akad ḥawālah dapat diperluas aplikasinya bukan hanya pada anjak piutang. Hal ini karena dalam anjak piutang, inisiatif untuk melakukan pengalihan adalah orang yang berpiutang bukan orang yang berutang. Ini sesuai dengan namanya, anjak piutang, yang berasal dari kata anjak yang berarti pindah atau alih dan kata piutang yang berarti tagihan sejumlah uang (Anshori, 2006: 20-21). Begitu juga jika dilihat dari definisi terminologinya, anjak piutang diartikan sebagai kegiatan pembiayaan dalam bentuk pembelian dan atau pengalihan serta pengurusan piutang atau tagihan jangka pendek suatu perusahaan dari transaksi perdagangan dalam dan luar negeri (Anshori, 2006: 21). Karena itulah, penulis menawarkan ide produk pembiayaan multijasa berdasar akad ḥawālah bi al-ujrah. Dalam akad ini, pembiayaan dapat diminta atau atas inisiatif pengutang maupun terutang.

\section{Pembentukan Konsep Pembiayaan Multijasa Berdasar Akad Hawālah}

Pembiayaan multijasa dengan berdasar akad ḥawālah dapat melalui tiga alternatif. Alternatif pertama, menggunakan akad ḥawālah semata. Sedang alternatif kedua dan ketiga sebenarnya merupakan akad hibrid ('uqūd murakkabah) atau multi akad, yang merupakan gabungan dua akad atau lebih dalam satu kesepakatan baru. Semua alternatif tersebut berpedoman pada dibolehkannya utang ghayr lāzim dalam akad ḥawālah sebagaimana pendapat madzhab Hambali di atas.

Berkumpulnya dua akad dalam satu kesepakatan (ijtimā' al-'uqūd al-muta'addidah fí șafqāt wāhidah) atau multi akad dalam produk LKS kontemporer adalah diperbolehkan oleh mayoritas ahli fikih. Multi akad yang dilarang hanyalah bentuk pengecualian dari keumuman kaidah mu'āmalah yang mendasarkan pada kebolehan semua akad kecuali yang dilarang oleh syara'. Pendapat ini juga lebih sesuai dengan tujuan syariah (maqāṣid shariah), yaitu adanya kemudahan dalam muamalah, keringanan dalam beban dan memberi peluang inovasi, serta lebih relevan dengan perkembangan zaman dan kebutuhan manusia akan transaksi dan akad-akad modern (Hammād, 2001: 249-275).

Namun kebolehan multi akad tersebut harus sesuai dengan batasanbatasan dan koridor syariah, agar tidak termasuk akad ganda yang dilarang 
oleh teks-teks syariah, baik melalui pemahaman teks tersebut maupun berdasarkan analogi (qiyas) karena kesamaan illat. Batasan-batasan syariah tersebut adalah: a) Multi akad tersebut tidak dilarang dalam nas shar'i; b) Multi akad tersebut tidak menjadi sarana ke suatu yang diharamkan; c). Multi akad tersebut tidak dijadikan sebagai hịlah (siasat) untuk mengambil riba dengan jalan lain (Hammād, 2001: 253-269).

Akad yang penulis gabungkan dalam pembiayaan multijasa ini adalah akad ḥawālah bi al-ujrah (ḥawālah dengan imbalan) dan wakālah (perwakilan), yang digabungkan dalam satu kesepakatan (kontrak). Kedua akad tersebut dibolehkan oleh ahli fikih secara sendiri-sendiri dan juga telah ditetapkan fatwanya oleh DSN MUI: ḥawālah bi al-ujrah ditetapkan dalam fatwa No. 58/DSN-MUI/V/2007, sedang wakālah ditetapkan dalam fatwa No. 10/DSNMUI/IV/2000. Begitu juga jika kita timbang/ukur dengan batasan-batasan kebolehan multi akad di atas, maka multi akad yang merupakan kumpulan dari akad ḥawālah bi al-ujrah dengan akad wakālah ini diperbolehkan.

Secara garis besar konsep pembiayaan multijasa berdasar akad ḥawālah ini mekanismenya ada tiga alternatif, yaitu:

Alternatif pertama: alternatif ini menggunakan akad hawālah semata. Mekanismenya hampir sama dengan pembiayaan multijasa dengan menggunakan akad ijārah. Hanya saja pembiayaan dengan akad hawālah ini lebih sempit, karena hanya pada objek utang yang telah ada pada tanggungan nasabah. Begitu juga alternatif ini hanya efektif jika LKS mempunyai jalinan kerjasama dengan pihak ketiga, tempat nasabah mempunyai tanggungan. Jalinan kerjasama ini tidak harus secara langsung atau khusus, tetapi dapat secara umum, misalnya pihak ketiga tersebut telah membuka diri dengan layaanan online yang memungkinkan pihak lembaga keuangan syariah mentransfer utang nasabah secara langsung dari kantor.

Alternatif pertama ini mekanismenya adalah sebagai berikut: 1) Nasabah melakukan transaksi dengan pihak ketiga sehingga menimbulkan tanggungan kepadanya seperti pendaftaran sekolah anaknya, pesan makanan atau lainnya; 2) Nasabah datang ke LKS meminta pembiayaan multijasa IB berdasar akad ḥawālah dengan membawa bukti utang, seperti surat tagihan, surat pemesanan atau lainnya serta persyaratan lainnya. Jika LKS menyetujui permintaan nasabah tersebut dengan imbalan (fee) tertentu yang disepakati, 
maka kedua belah pihak (LKS dan nasabah) menandatangani pembiayaan multijasa dengan akad ḥawālah bi al-ujrah; 3) Pihak LKS kemudian mentransfer uang sejumlah tanggungan nasabah yang menjadi objek ḥawālah kepada pihak ketiga; 4) Nasabah membayar utangnya yang telah dialihkan ke LKS ditambah fee (ujrah) yang disepakati secara angsuran dalam batas waktu yang telah disepakati.

Alternatif kedua: alternatif ini menggunakan akad hibrid, yaitu penggabungan antara ḥawālah bi al-ujrah dengan wakālah. Secara garis besar mekanisme dari pembiayaan multijasa IB dalam alternatif ini adalah sebagai berikut: 1) Nasabah melakukan transaksi dengan pihak ketiga sehingga menimbulkan tanggungan kepadanya seperti pendaftaran sekolah anaknya, pesan makanan atau lainnya; 2) Nasabah datang ke LKS meminta pembiayaan multijasa IB berdasar akad hawālah dengan membawa bukti utang, seperti surat tagihan, surat pemesanan atau lainnya serta persyaratan lainnya. Jika permintaan nasabah tersebut disetujui dengan imbalan (fee) tertentu yang disepakati, maka kedua belah pihak (LKS dan nasabah) menandatangani pembiayaan multijasa dengan akad ḥawālah bi al-ujrah; 3) Kemudian LKS membuat akad wakālah dengan nasabah agar nasabah tersebut menjadi wakil LKS dalam membayarkan tanggungan nasabah yang di-ḥawālah-kan kepada LKS tersebut yang diikuti dengan penyerahan uang sejumlah tanggungan atau utang nasabah yang menjadi objek ḥawālah dari LKS kepada nasabah untuk dibayarkan kepada pihak ketiga; 4) Nasabah datang kepada pihak ketiga untuk melunasi utangnya atas nama LKS; 5) Nasabah membayar utangnya yang telah dialihkan ke LKS ditambah fee (ujrah) yang disepakati kepada LKS secara angsuran dalam batas waktu yang disepakati bersama.

Alternatif ketiga: alternatif ini juga menggunakan akad hibrid, berupa gabungan antara akad ḥawālah bi al-ujrah dengan akad wakālah. Secara garis besar mekanisme pembiayaan ini adalah sebagai berikut: 1) Nasabah yang membutuhkan pembiayaan seperti untuk pernikahan, sekolah atau lainnya, datang ke LKS untuk negosiasi awal. Setelah melihat proposal pembiayaan, LKS berjanji (wa'd) untuk melakukan ḥawālah tatas utang nasabah ketika nasabah telah melakukan transaksi yang menimbulkan tanggungan atau utang pada pihak lain; 2) Berpegang pada janji LKS tersebut, nasabah melakukan transaksi yang diinginkan dengan pihak lain 
(pihak ketiga) sehingga menimbulkan tanggungan nasabah kepada pihak ketiga tersebut; 3) Nasabah datang ke LKS dengan membawa bukti utang dari pihak ketiga kemudian kedua belah pihak menandatangani akad hawālah bi al-ujrah; 4) kemudian LKS membuat akad wakālah dengan nasabah agar nasabah tersebut menjadi wakil LKS dalam membayarkan tanggungan nasabah yang di-ḥawālahkan kepada LKS tersebut. yang diikuti dengan penyerahan uang sejumlah tanggungan atau utang nasabah yang menjadi objek ḥawālah dari LKS kepada nasabah untuk dibayarkan kepada pihak ketiga; 5) Nasabah datang kepada pihak ketiga untuk melunasi tanggungannya atas nama lembaga keuangan syariah; 6) Nasabah membayar utangnya yang telah dialihkan ke LKS ditambah fee (ujrah) yang disepakati kepada LKS secara angsuran.

Ketiga alternatif pembiayaan multijasa berdasar akad ḥawālah di atas dapat digunakan berdasar kebutuhan. Alternatif pertama dapat dilakukan jika pihak LKS telah menjalin kerjasama dengan pihak ketiga. Alternatif kedua dan ketiga jika pihak LKS dengan pihak ketiga belum ada kerjasama. Alternatif kedua bagi nasabah yang sudah sangat yakin bahwa proposal pembiayaannya pasti diterima oleh LKS. Keyakinan ini berdasar beberapa sebab: pertama, dari segi finansial, yang mengajukan adalah nasabah yang bankable seperti PNS dan lainnya; kedua, dari segi pembiayaan, yang diminta tidak terlalu besar; ketiga, nasabah telah dikenal baik kejujuran dan amanahnya oleh LKS. Sedang alternatif kedua dapat digunakan bagi nasabah yang tidak begitu yakin kalau proposal pembiayaannya diterima oleh LKS, sehingga dia perlu kepastian dari LKS terlebih dahulu sebelum melakukan transaksi.

\section{Penutup}

Berdasarkan paparan di atas dapat disimpulkan bahwa akad ḥawālah selama ini belum banyak dikembangkan oleh LKS. Aplikasi perbankan dengan berdasar akad hawālah masih sedikit dan belum populer. Padahal dengan sedikit inovasi, akad ḥawālah dapat dijadikan alternatif bagi pembiayaan multijasa. Inovasi tersebut berupa penggabungan akad hawālah bi al-ujrah dengan akad wakālah. Bahkan berdasar studi di atas, pembiayaan multijasa syariah dengan berbasis akad hawālah bi al-ujrah digabung dengan 
akad wakālah lebih kompetitif dan lebih luas jangkauannya dengan pembiayaan multijasa yang selama ini di jalankan oleh LKS dengan berdasarkan fatwa DSN MUI tentang pembiayaan Multijasa, yaitu berdasar akad ijārah dan kafālah.

DSN MUI perlu menguji studi lain terkait dengan produk perbankan syariah sehingga kemudian dapat dihasilkan fatwa yang lebih tepat dan aplikatif. Sehingga harapannya inovasi produk LKS akan semakin variatif dan memudahkan sehingga produk-produk LKS semakin kompetitif dan tidak kalah bersaing dengan perbankan konvensional dalam kemudahan layanan. Wallāhu a'lam.

\section{Daftar Pustaka}

Al-Maliqi, 'Aishah al-Sharqawi. 2000. Al-Bunūk al-Islāmiyyah, al-Tajribah Baina al-Fiqh wa al-Qānūn wa al-Tațbīq. Beirut: al-Markaz alThaqafi al-'Arabi.

Al-Salus, Ali Ahmad. 2004. Fiqh al-Bai' wa al-Istithāq wa al-Tatbīq al-Mu'āṣir. Beirut: Muassasah al-Rayyān.

Al-Ṣan'ani, Muhammad ibn Ismail. 1991. Subul al-Salām Sharh Bulūghu al-Marām, Vol. 3. Beirut: Dār al-Fikr.

Al-Zuhayli, Wahbah. 2007. Al-Fiqh al-Islāmy wa Adillatuhu. Beirut: Dār alFikr al-Mu'āșir, vol. 6.

Anshori, Abdul Ghofur. 2006. Gadai Syariah di Indonesia, Konsep, Implementasi dan Institusionalisasi. Yogyakarta, Gajahmada University Press.

Antonio, Muhammad Syafi'i. 2001. Bank Syariah dari Teori ke Praktek. Jakarta: Gema Insani Press.

'Atiqi, Muhammad Kull. 1998. Bai' al-Dayn Șuwaruhu wa Ahkāmuhu: Dirāsah Muqāranah, Majallah al-Sharī'ah wa al-Dirāsāt alIslāmiyyah, tahun 13, Vol 35.

Chapra, M. Umer. 2000. Sistem Moneter Islam. Terj. Ikhwan Abidin Basri. Jakarta: Gema Insani Press.

DSN-MUI. Kumpulan Fatwa Dewan Syariah Nasional MUI.

Ḥammād, Nazih. 1995. Mu’jam al-Muṣțalahāt al-Iqtisādiyyah fí Lughati alFuqahā'. Riyadh: Al-Dār al-'Ālamiyyah li al-Kitāa al-Islāmy. 2001. Qaḍayā Fiqhiyyah Muāṣirah fĩ al-Māl wa al-Iqtiṣād. Damaskus: Dār al-Qalam. 
Muhamad. 2004. Dasar-Dasar Keuangan Islami. Yogyakarta: Ekonisia.

www.bi.go.id/web/id/perbankan/perbankan+syariah, diambil pada tanggal 10 Oktober 2010.

www.bi.go.id/web/id/statistik/statistik+perbankan+indonesia/spi.0410.htm, diambil pada tanggal 10 Oktober 2010. 